\title{
Classification of shallow water seabed profile based on Landsat 8 imagery and in-situ data. Case study in Gili Matra Island Lombok, Indonesia
}

\author{
Ratih Ayustina ${ }^{1}$, Zahra Aulia ${ }^{1}$, Haji Mustakin ${ }^{1}$, Fiyesti Alam ${ }^{1}$, Amron Amron ${ }^{* 1}$, Doddy \\ Yuwono $^{2}$, Triguardi Ahmad ${ }^{1}$, Aldo Prayogo ${ }^{1}$, and Fitra Sari ${ }^{1}$ \\ ${ }^{1)}$ Department of Marine Science, Faculty of Fisheries and Marine Science Jenderal Soedirman \\ University, Purwokerto Indonesia \\ ${ }^{2)}$ Center for Thematics Mapping and Integration, Geospatial Information Agency, Cibinong Indonesia
}

\begin{abstract}
Shallow water seabed profile has considerable potential resources so the availability of information which very important for coastal resources. The use of remote sensing techniques is considered to provide coastal information effective and efficient. This research aimed to determine the shallow water seabed profile based on Landsat 8 Imagery and its accuracy related to the in situ data. Methods of this research are satellite mage pre-processing, image classification, field survey, image classification, and accuracy assesment . Therefore, 6 classification of shallow water seabed profile, there are rubble $(\mathrm{R})$, seagrass mixed sand (MIX -SG/SD), coral reefs mixed rubble (MIX-C/RB), rubble mixed dead coral (MIX-RB/DC), sand mixed rubble (MIX-SD/RB), and sand mixed seagrass (MIX-SD/SG), respectevely. The result of this classification has an accuracy value $80 \%$.
\end{abstract}

\section{Introduction}

The shallow water seabed profiles potentially coastal resources, so it must be managed well in order to be optimally and sustainably utilized. Potential coastal areas such as fishery assets, marine tourism, energy, maritime industry and marine development activities[1]. One example of its management can be done using remote sensing for later mapping [2]. According Diaz et al. [3] by being able to map the basic objects of shallow water would be useful to assess the state of resources in the area.

One way to get information on coastal resources is to use remote sensing. The use of remote sensing is done because the conventional method is considered less efficient in providing a profile of shallow seabed profile in addition to require a long time is also a relatively expensive cost considering that the region is generally located in remote areas and access difficult. Therefore, the use of remote sensing satellite imagery as an alternative is the most ideal way to answer those needs and is considered effective and efficient for

$*^{1}$ Corresponding Author: twoone_brond@scientist.com 
obtaining spatial information, whose results are useful as basic information in the preparation and preparation of coastal area management plans [4]. Through this technology, information of an object can be obtained using satellite sensors and then analyzed and presented in spatial and thematic form in accordance with the purpose of the activity [5].

The Landsat- 8 Satellite Imagery is considered a potential satellite as a medium for monitoring and obtaining information on shallow underwater objects [6], which has short recording times about 16 days [7] and having a blue spectral band to identify shallow sea floor objects [8]. The advantages of this satellite image also have medium resolution on the multispectral band of 30 for the study of aquatic objects [9]. The use of Landsat- 8 Satellite Imagery in this study is considered appropriate to obtain information on shallow water sea bed profiles in Gili Matra. This is in accordance with the direction of this study which aims to determine the shallow water sea bed profile of Gili Matra (Gili Meno, Gili Air, and Gili Trawangan), Lombok NTB and its accuracy based on Landsat-8 satellite images and in situ data.

\section{Materials and Methods}

\subsection{Study Site}

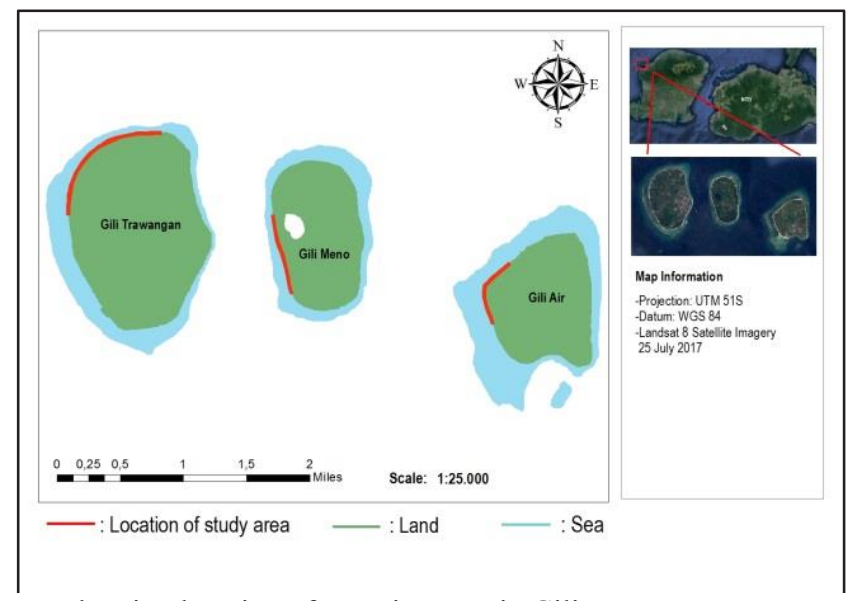

Fig 1. Index map showing location of mapping area in Gili Matra

The study area in this study is located on Gili Matra Islands covering Gili Meno, Gili Air and Gili Trawangan (Figure 1). In accordance with the database owned by Indonesian Marine and Fisheries Minsistry, Taman Wisata Perairan Gili Meno, Air dan Trawangan with an area of 2,954 hectares, which covers the land area of Gili Air \pm 175 ha with the circumference of the island $\pm 5 \mathrm{~km}$, Gili Meno \pm 150 ha with around the island $\pm 4 \mathrm{~km}$ and Gili Trawangan \pm 340 ha with a circumference of the island $\pm 7.5 \mathrm{~km}$ and the rest is marine waters. Geographically TWP Gili Matra is located at $8^{\circ} 20^{\prime} 00^{\prime \prime}-8^{\circ} 23^{\prime} 00^{\prime \prime}$ S and $116^{\circ} 00^{\prime} 00^{\prime \prime}$ $-116^{\circ} 08^{\prime} 00^{\prime \prime}$ E. Site selection is based on the diversity and variability of the shallow water seabed profile of pre-survey image processing results assessed as representative for mapping by Landsat-8 OLI record of July 25, 2017. Gili Matra waters have high marine resources potential including their biotas because the waters of Lombok have warm water temperatures and their tidal characteristics are influenced by the cyclone winds in the Indian Ocean. Thus, water conditions in the western seasons of high air humidity, good irradiation, low salinity, and sediment composition are composed of medium to rough sand, coral fragments and other biota. 


\subsection{Satellite Image Pre Processing}

Satellite image pre-processing consists of radiometric correction, reflectance correction, water column correction, masking and cropping. Radiometric correction is performed to improve image quality due to atmospheric disturbances, such as haze scattering or other object scattering [10]. Radiometric correction includes radiance correction and reflection correction (Convertion From Radiance at Sensor to ToA Reflectance). The correction of radians done is::

$$
L \lambda^{\prime}=L Q c a l+A L
$$

where :

$L \lambda^{\prime} \quad$ : radian spectral on sensor $\left(\mathrm{W} / \mathrm{m}^{2} \operatorname{str} \mu \mathrm{m}\right)$

Qcal : pixel value (DN)

$\mathrm{M}_{\mathrm{L}} \quad$ : rescalling constant

(RADIANCE_MULTI_BAND_x,band used)

$\mathrm{A}_{\mathrm{L}} \quad$ : adders constant (RADIANCE_ADD_BAND_x, band used)

Meanwhile, for reflectance correction on using the following formula::

where:

$$
\rho \lambda^{\prime}=\rho Q \operatorname{cal}+A \rho / \operatorname{Cos}(\theta \mathrm{s})
$$
$\rho \lambda^{\prime} \quad$ :the result of processing without the retrieval correction, $\rho \lambda^{\prime}$ does not contain correction for the sun angle
Qcal :pixel value (DN)
$\mathrm{M} \rho \quad$ :rescalling constant
(RADIANCE_MULTI_BAND_x, band used)
A $\rho \quad$ : konstanta penambah

(RADCIANCE_ADD_BAND_x, band used)

$\operatorname{Cos}(\theta \mathrm{s})$ : sun zenith angle (90 - angle of sun elevation), where $(\mathrm{Cos}(\operatorname{Rad}(90$-angle of sun elevation)).

Image sharpening to see shallow water seabed profile using an approach of band transformation, the Depth Invariant Index (DII) algorithm [34]. The algorithm uses band 2 and band 3 . The basic use of band 2 and band 3 is that both bands have good penetration into the water column [35]. The algorithm used following the BIG (2014) are:

where:

$$
Y=(\ln \text { Band1-Band1 Deep) }-k i / k j *(\operatorname{lnBand2}-\text { Band2 Deep })
$$

$$
\begin{array}{ll}
\text { Y } & \text { : result of lyzenga algorithm } \\
(\ln (\text { Band1) } & \text { : natural blue band logarithm } \\
(\mathrm{ki} / \mathrm{kj}) & : \text { variance and covariance values on blue and green bands } \\
(\ln (\mathrm{Band} 2) & : \text { natural green band logarithm. } \\
\text { Band Deep } & : \text { pixel value of the band-i in the deep sea }
\end{array}
$$

The process of masking and cropping aims to limit the area of image analysis. In the image analysis for shallow water, it is necessary to separate the land and water, so that the analysis process is only done on the water zone. Masking and cropping can be done using either the pixel value threshold on a given object to be digitally analyzed or through a 
digitization process [10]. Then do the sampling area at least 30 dots. Point retrieval is done by using the same colored substrate point that allegedly represents the shallow water seabed profile [11].

\subsection{Field Survey}

The field survey was conducted on 07-11 August 2017. Field data was collected by determining the observation point that was considered to have represented each object based on the variation of the seabed profile condition of the waters of the processed satellite images true color [12]. Field data were collected using Rapid Reef Assessment (RRA) techniques to obtain shallow water sea bed profile [13]. Intake of the shallow water seabed profile is done by photographing the object in the field every 15 meters once continuously within the RRA area, this is due to the results obtained because Landsat 8 image has a spatial resolution of 30 meters [6] so that sampling every 15 to anticipate the pixel errors . Furthermore, recording the number of photos and GPS together with the recording of objects observed in the field [14]. Then the GPS is placed in the housing and tied up with the data taker (cultivated GPS remains on the surface) to record tracking during the data retrieval of baseline objects [15].

\subsection{Image Classification}

The classification taken is a supervised classification, because according to [16] high resolution image is suitable to use guided classification, this process includes the analyst doing the training on the image pixel area that has been sampled the object when the field survey. Sampling is expected to be evenly distributed so that the computer device is able to recognize the pixel as a particular object. Then use the maximum likelihood classifier to display image classification using field data obtained from photographs in the field [12]. Classes built for image classification refer to Ball et al. [17] as Table $\mathbf{1}$

Table 1. Table of Classification

\begin{tabular}{ll}
\hline \multicolumn{1}{c}{ Class } & \multicolumn{1}{c}{ Characteristics } \\
\hline Coral + Rubble (MIX-C/RB) & Dominant coral, but has rubble \\
Sand + Seagrass (MIX-SD/SG) & Dominant sand but has seagrass \\
Rubble (RB) & $100 \%$ Rubble \\
Seagrass + Sand (MIX-SG/SD) & Dominant seagrass but has sand \\
Sand + Rubble (MIX-SD/RB) & Dominant sand but has rubble \\
Rubble + Dead Coral (MIC-RB/DC) & Dominant rubble but has dead coral \\
\hline
\end{tabular}




\subsection{Accuracy Assesment}

Data obtained from the field survey are for accuracy assesment, re-classification and reanalysis to determine the baseline profile of the waters. The results of the accuracy assesment affect the level of user confidence in the data type and the method of analysis [18]. The accuracy assesment can be done using the table of confusion matrix as shown in Table 2. The total samples obtained in the field, some $(50 \%)$ are used in digital multispectral classification process and others (50\%) are used for accuracy assesment's classification [19].

Table 2. Table confussion matrix based on[33]:

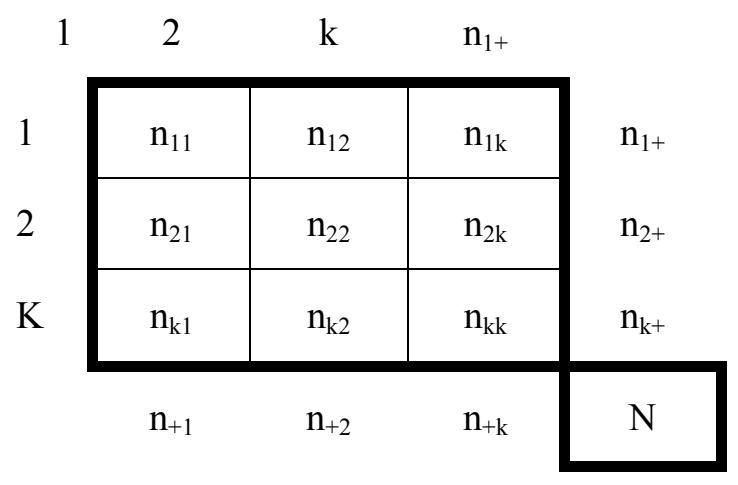

\section{Result and Discussion}

\subsection{Shallow water seabed profile}

Sampling data in the field was obtained 193 points and there were 156 points correctly classified into satellite image class. The sample class is built based on the objects obtained in the field. Based on samples taken in the field, Rubble and MIX-SG / SD classes have the Highest number of classified and most-sampled samples, while the MIX-SD/SG class has the lowest number of classified and accurate samples (Table 3) 
Table 3. Detailed samples of shallow water seabed profile based on field data.

\begin{tabular}{|c|c|c|c|}
\hline Class & Characteristics & $\begin{array}{r}\text { Classified } \\
\text { Sample }\end{array}$ & ccurated Sample \\
\hline $\begin{array}{l}\text { Coral + Rubble (MIX- } \\
\text { C/RB) }\end{array}$ & $\begin{array}{l}\text { Dominant coral, but has } \\
\text { rubble }\end{array}$ & 37 & 33 \\
\hline $\begin{array}{l}\text { Sand + Seagrass } \\
(\mathrm{MIX}-\mathrm{SD} / \mathrm{SG})\end{array}$ & $\begin{array}{l}\text { Dominant sand but has } \\
\text { seagrass }\end{array}$ & 12 & 4 \\
\hline Rubble (RB) & $100 \%$ Rubble & 50 & 48 \\
\hline $\begin{array}{l}\text { Seagrass + Sand } \\
(\text { MIX-SG/SD) }\end{array}$ & $\begin{array}{l}\text { Dominant seagrass but has } \\
\text { sand }\end{array}$ & 50 & 47 \\
\hline $\begin{array}{l}\text { Sand+ Rubble (MIX- } \\
\text { SD/RB) }\end{array}$ & $\begin{array}{l}\text { Dominant sand but has } \\
\text { rubble }\end{array}$ & 13 & 6 \\
\hline $\begin{array}{l}\text { Rubble + Dead Coral } \\
\text { (MIC-RB/DC) }\end{array}$ & $\begin{array}{l}\text { Dominant rubble but has } \\
\text { dead coral }\end{array}$ & 31 & 18 \\
\hline Total & & 193 & 156 \\
\hline
\end{tabular}

This is the appearance of the shallow water seabed profield in the field recorded by underwater cameras which has been classified into 6 classes, ie:
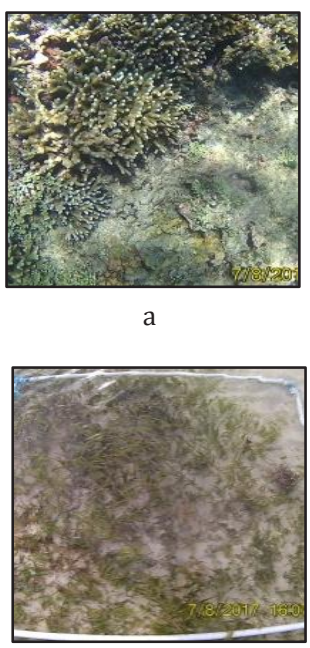

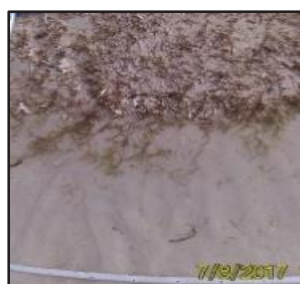

b

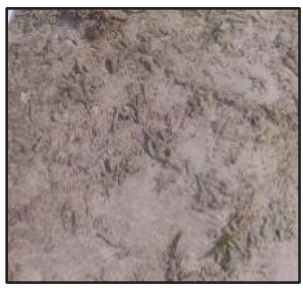

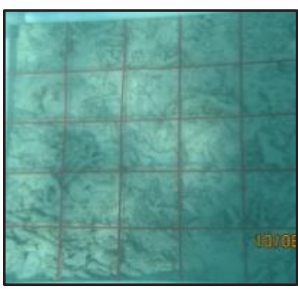

C

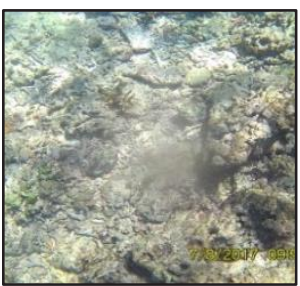

Fig 2. An gverview of the common object variations appears in the field and is used as a feference for constructing the base substrate cover class in guided classification (a) MIX-C/RB (b) MIX-SD/SG (c) RB (d) MIX-SG/SD (e) MIX-SD/RB (f) MIX-RB/DC

Based on observation and data collection in the field, the dominant object is found rubble and the mixture between seagrass and base substrate (sand). The amount of rubble found in Gili Matra is caused by environmental conditions that are experiencing global warming and human activities are less conservative such as placing anchors at random when the ship is docked, and tourists who are less used to doing snorkeling so that many seabed objects are damaged by the activity on while swimming. This is consistent with the opinion of Setiawan et al [20], during 2012 to 2017 in Gili Matra there are many dead corals found due to extreme high or low water temperatures, and this is associated with global warming where corals include animals with low temperature tolerance. While seagrass and substrate are easy to find in Gili Matra because its distribution is very wide along the coast of Gili Matra. Seagrasses in the coastal waters of Lombok island can be 
found in intertidal areas almost along the coast including on small islands such as Gili Air, Gili Meno, and Gili Trawangan

The differences in data points in the field and correctly classified points can be due to misclassification due to the difference in the delicate spectral values, as well as the object classes in the field that cohere its existence [21]. The distance of sampling in the adjacent field is also the cause of the result of an accurate object on the map. So that, in some samples of objects with a narrow distribution in the field the results are less than optimal [18], consequently the number of points that are accurate and classified there are differences.

The most classified and accurate class of samples can be due to the relatively uniform homogeneity and spatial distribution in the field. Highly classified and accurate grades are reinforced by field conditions stated by Setiawan et al. [20] he stated that Gili Matra dominantly found rubble and gratitude statement (2015) that seagrasses tend to be in the intertidal region of Gili Matra. In the image aspect, Landsat- 8 Satellite Imagery is suitable for mapping seagrass and basic substrate on a wide scale [22,23,24]

The used of the class naming in this study is the result of interpretation in the field, because there has not been a standard naming class to a more detailed level in benthic object mapping [25]. This is in line with what the Geospatial Information Agency (BIG) discloses only 4 general classes for mapping the shallow water seabed profile, ie coral reefs, seagrass beds, macroalgae and substrate (BIG, 2014). Regardless of the naming context, however, the use of Landsat- 8 Satellite Imaagery in this research is one of the efforts of optimizing remote sensing media in monitoring and providing coastal information in accordance with the research done by Hafizt et al. [18] benthic habitat in shallow waters by using Landsat-8 Satellite Image.

\subsection{Classification of Shallow Water Seabed Profile in Gili Matra}

The shallow water seabed profile that has been classified into 6 classes are corals mixed rubble (MIX-C / RB) which means that in the area corals are dominant but algae still exist, sand mixed seagrass (MIX-SD / SG) which means that in the area sand are dominant but seagrass still exist, rubble class (RB) which means that in that area dominated by rubble, seagrass mixed sand (MIX-SG / SD) which means that in the area seagrass are dominant but sand still exist, sand mixed rubble (MIX-SD / RB ) which means that in the sand are dominant but rubble still exist, rubble mixed dead coral (MIX-RB / DC) which means that in the area rubble are dominant but dead coral still exist, (Figure 3).

Based on the classification, the distribution of MIX-C / RB classes tends to be on the outer edge, because the coral reefs in Gili Matra include the fringing reef group that is near the coral reef and parallel to the coastline. Some examples of the types of edge reefs present in Indonesia are in the Mentawai, Pangandaran and Parangtritis areas on the southern coast of Java Island, Lombok and Sumbawa, East Nusa Tenggara and north and west of Papua [1]. While MIX-RB / DC and rubble classes tend to be found in flat areas caused by waves and strong currents carrying rubble and dead corals toward the shore. This is in accordance with the statement of McKenzie and Yoshida [26] that coral reef ecosystems in Gili Matra are often encountered dead coral this is caused by anthropogenic activities such as cruise lines where the decline of the anchor can damage the coral reef ecosystem. Furthermore the class, MIX-SG / SD tends to be close to the mainland where the seagrass habitat is adjacent to the shore. Locations of seagrass beds in accordance with the statement of Nurdin et al. [27]where the presence of seagrass cover and sand are in shallow waters with a depth ranging from 0-1,5 meters. Shallow and clear areas where seagrasses breed. As flowering plants that acclimatise to drown in the sea, the seagrasses 
flourish in the waters with the foundation of mud, sand, gravel and dead coral fractures with the seabed still penetrating sunlight.

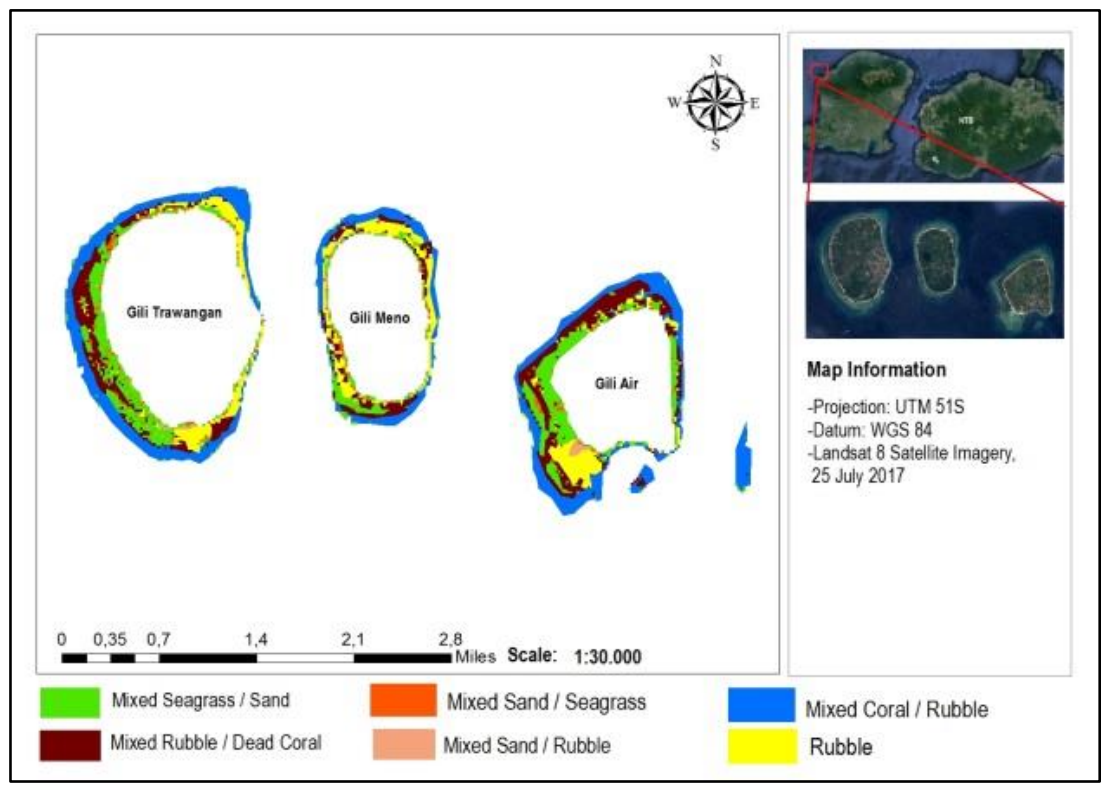

Fig. 3. Map of classification shallow water seabed profile in Gili Matra

\subsection{Accuracy Assesment of Shallow Water Seabed Profile}

The overall accuracy of the baseline shallow end surface of shallow seabed profiles from Landsat-8 Satellite Imagery is $80 \%$. The lowest accuracy user is the MIXSD / SG class and the highest is Rubble. Meanwhile, the lowest Accuracy Producer is MIX-SD / RB and the highest is MIX-C / RB (Table 4).

Table 4. Accuracy Assesment Based On Landsat 8 Satellite Imagery

\begin{tabular}{lccccccc}
\hline & $\begin{array}{c}\text { mix- } \\
\text { C/RB }\end{array}$ & $\begin{array}{c}\text { mix- } \\
\text { SD/SG }\end{array}$ & RB & $\begin{array}{c}\text { mix- } \\
\text { SG/SD }\end{array}$ & $\begin{array}{c}\text { mix- } \\
\text { SD/RB }\end{array}$ & $\begin{array}{c}\text { mix- } \\
\text { RB/DC }\end{array}$ & UA \\
\hline mix-C/RB & 33 & 0 & 2 & 0 & 0 & 2 & $\mathbf{8 9 , 1 8 \%}$ \\
mix-SD/SG & 0 & 4 & 2 & 4 & 2 & 0 & $\mathbf{3 3 \%}$ \\
RB & 2 & 0 & 48 & 0 & 0 & 0 & $\mathbf{9 6 \%}$ \\
mix-SG/SD & 0 & 1 & 2 & 47 & 0 & 0 & $\mathbf{9 4 \%}$ \\
mix-SD/RB & 0 & 1 & 1 & 5 & 6 & 0 & $\mathbf{4 6 , 1 5 \%}$ \\
mix-RB/DC & 4 & 1 & 4 & 4 & 0 & 18 & $\mathbf{5 8 \%}$ \\
PA & $\mathbf{8 4 , 6 1 \%}$ & $\mathbf{5 7 , 1 4} \%$ & $\mathbf{8 1 , 3 5 \%}$ & $\mathbf{7 8 , 3} \%$ & $\mathbf{2 5 \%}$ & $\mathbf{9 0 \%}$ & \\
\hline OA & & \multicolumn{7}{c}{} & $\mathbf{8 0 \%}$ \\
\hline
\end{tabular}

The overall accuracy obtained in this study is $80 \%$, it is already high [28], referring to the statement of Green et al. [4] that the accuracy can be used is an overall accuracy test of 
more than $60 \%$, and also reinforced by the opinion of Ambodo et al. [28] that the accuracy test of $60 \%$ can be said to be good. The results of good accuracy in this study can be caused by several possibilities, one of them is about the the recording time from satellite imagery which processed, does not vary too much with the field survey, where the Landsat 8 Satelite Imagery recording in July 2017 and field survey conducted in August 2017. This is reinforced by the opinion Harvini [29] which states that the results of image recording with the time of research conducted affect the test accuracy, because of the possibility that the field conditions have changed.

The low level of user accuracy and producer accuracy could be due to difficulty of position matching between imagery and field data such as image position shift with GPS causing deplacement of observed object location [30]. In addition, the number of sample variations in the field also affects the results of accuracy [4]. Image errors in describing objects can also result in low accuracy values because objects that are described by image do not match the observed objects in the field, then the proportion of too few samples in a sample is compared with other samples [18].

According to [4] that the accuracy of the shallow marine habitat mapping that can be used is with an overall accuracy of $>60 \%$. [18] mapped the basic habitat of shallow sea waters using Landsat- 8 imagery to produce accuracy of $47.57 \%$ with 7 classes of cover. In other research, produced $76 \%$ accurate benthic habitat maps with 4 classes [8], while Marlina [18] resulted in 84\% map accuracy with 5 classes of coral reef habitat, while Phin et al. [31] yielded 57\% accuracy with a relatively high classification class of 20 classes. The emergence of mapping accuracy differences from several studies using Landsat-8 Satellite imagery was due to differences in classification methods, number of field observation points, number of benthic habitat classes and study sites..

As stated by Hafizt et al. [18] that if by using Landsat-8 Satellite Imagery capable of achieving high accuracy, then in observing the dynamics of changing coastal conditions of Indonesia can utilize Landsat-8 Satellite Imagery that can record data on a regular basis. In addition, Landsat-8 Satellite Imagery that is open access is also suitable for mapping coastal conditions of tropical regions such as Indonesia with the object of the sea floor tends to be encountered are coral reefs and sea grass beds [32].

\section{Conclusion}

The use of Landsat- 8 Satellite Imagery to map the shallow bottom profile profile in Gili Matra resulted in 6 classes of shallow bottom substrate covering the rubble mixed rock (MIX-K / RB), mixed seagrass sand (MIX-SD / PL), rubble (RB), sand mixture (MIX-PL / SD), mixed rubble (MIX-SD / RB), dead coral rubble (MIX-RB / DC) and Landsat-8 Satellite Imagery are said to be good enough to map shallow sea floor objects in coastal areas.

The authors would like to thank the Head of Gili Matra Village who has been pleased to provide accommodation to us while collecting data in Gili Matra, Mr. Amron and Mr. Doddy who helped to review and review the manuscript of this journal, to the expedition team HIMAKEL III Jenderal Soedirman University for support and trust to us, as well as all parties who have helped in the data collection and writing of this journal.

\section{References}

1 Dahuri R. Naskah Orasi Ilmiah Pengukuhan Guru Besar Tetap Ilmu Pengelolaan Sumberdaya Pesisir dan Lautan. (Institut Pertanian Bogor, Bogor, 2003) 
2 Lillesand, dan Kiefer. Penginderaan Jauh dan Interpretasi Citra. (Gadjah Mada University Press, Yogyakarta, 1999)

3 J.R. Diaz, M. Solan, M.R. Valente. J. Environ Manag. 73, 165-181 (2004)

4 E. P. Green, P.J. Mumby, A.J. Edwards, and C.D. Clark. Remote Sensing Handbook for Tropical Coastal Management. (UNESCO, Paris, 2000)

5 A.F. Syah. Jurnal Kelautan. 03, 18-28 (2010)

6 USGS. Landsat 8 (L8) Data Users Handbook. (Department of the Interior U.S, U.S. Geological Survey, 2015)

7 G. Sitanggang. Berita Dirgantara. 11, 47-58 (2010)

8 H.S. Murti, and P. Wicaksono. Majalah Globe. 16, 133-120 (2014)

9 J. Jensen. Remote Sensing of The Environment: an Earth Resource Perspective, 2nd edition. (Pearson Prentice Hall, United States of America, 2007)

10 B. Prayuda. Panduan Teknis Pemetaan Habitat Dasar Perairan Laut Dangkal. (Critc Coremap II LIPI, Jakarta, 2014)

11 T. Hariyanto, and A. Lingga. GEOID. 01, 171-175 (2016)

12 P. Wicaksono. 12th Biennial Conference of Pan Oceanic Remote Sensing Conference (PORSEC 2014, Bali Indonesia, 2014)

13 Dahlan. J. of Fish Dev. 1, 61-82 (2014)

14 A.B.M.A. Suriadi, Y. Siswantoro, S. Hartini, G.B. Saputro, D.M. Yuwono, D. Suhendra. Pedoman Survei dan Pemetaan Terumbu Karang. Pusat Survei Sumberdaya Alam Laut. (Badan Koordinasi Survei dan Pemetaan Nasional, Bogor, 2005)

15 C.M. Roelfsma, S.R. Phinn. A manual for Conducting Georefenced Photo Transect Surveys to Assess the Benthos of Coral Reef and Seagrass Habitats. (University of Queensland, Queensland: Centre, 2009)

16 P. Danoedoro. Pengantar Penginderaan Jauh Digital. (Penerbit ANDI, Yogyakarta, 2012)

17 D. Ball, S. Blake, A. Plummer. Review of Marine Habitat Classification System. (Parks Victoria, Melbourne, 2006)

18 M. Hafizt, Y.M. Iswaril, and B. Prayudah. Oseanologi dan Limnologi di Indonesia. 2,113 (2017)

19 P. Wicaksono, A.P. Aryaguna, and H. Akhyar. Pemetaan. Seminar Nasional Pengelolaan Pesisir \& Daerah Aliran Sungai ke-1. (Universitas Gadjah Mada, Yogyakarta, 2015) 
20 Setiawan. J. Fish. Mar. Sci. 1, 39-54 (2017)

21 F. Mafazi. Pemetaan Habitat Bentik Menggunakan Citra Quickbird di Sebagian Pulau Kemujan, Kepulauan Karimunjawa (UGM, Yogyakarta, 2014)

22 R. Shofiyati. Informatika Pertanian. 19, 109-124 (2010)

23 I.H. Supriyadi. Oseanologi dan Limnologi di Indonesia. 36, 147-164 (2010)

24 I.M. Sakaruddin. Komposisi Jenis, Kerapatan, Persen Penutupan, dan Luas Penutupan Lamun di Perairan Pulau Panjang Tahun 1990-2010. Skripsi. (Fakultas Perikanan dan Ilmu Kelautan. Institut Pertanian Bogor, 2011)

25 M. Hafizt. Inventarisasi Habitat Bentik Menggunakan Teknologi Pengindraan Jauh untuk Mendukung Program Pengelolaan Pesisir Terpadu di Pulau Kemujan Kepulauan Karimunjawa. (Universitas Gadjah Mada, Yogyakarta, 2015)

26 L.J. McKenzie, and R.L. Yoshida. The Nature Concervacy, Coral Triangle Center, Sanur. (Seagrass-Watch HQ Cairns. Bali, 2009)

27 N. Nurdin, T. Komatsu, C., Rani, G. Arafat, S.A.M. Akbar. Proceeding of SPIE Asia Pasific Remote Sensing, (Kyoto, Japan, 2012)

28 P. Ambodo, and R.H. Jatmiko. IPI Jurnal Bumi Indonesia. 1, 9-18 (2012)

29 W. Harvini. J.Bhumi. 3, 98-110 (2017)

30 V.P. Siregar. J. Ilm.Tekno.Kel.Trop. 2, 19-30 (2010)

31 V.D. Tran, S. Phinn, C. Roelfsma. Asian J. Geoinformatics. 12, 2 (2012)

32 N. Radiarta. Jurnal RIS Akuakultur. 2, 271-280 ( 2007)

33 G.R. Congalton. Int. J. of Wildland Fire. 10, 321-328 (2001)

34 D.R. Lyzenga. Applied Optics. 17, 379-383 (1978)

35 R.E. Mount. Photogrammetric Enginering and Remote Sensing. 71, 1407-1415 (2006)

Mumby, P.J., Green, E.P., Clarck, C.D., Edwards, A.J. 1999. Digital Analysis of Multispectral Airbone Imagery of Coral Reefs. Coral Reefs. 17:59-69.

Nybakken, J.W. 1988. Biologi Laut: Suatu Pendekatan Ekologis. [Terjemahan dari: Marine Biology: An ecologycal approach, 3rd ed]. Eidman HM, Koesoebiono, Bengen DG, Hutomo M \& Sukarjo S (penerjemah). PT Gramedia. Jakarta. $459 \mathrm{hlm}$.

Syukur. 2015. Distribusi, Keragaman Jenis Lamun (Seagrass) dan Status Konservasinya di Pulau Lombok. Jurnal Biologi Tropis. 15(2): 171-182. 
Wicaksono, P., Hafizt, M. 2013. Mapping Seagrass from Space: Adressing the Complexity of Seagrass LAI Mapping. Europan Journal of Remote Sensing. 46 : 18-39. 